\title{
OPTIMISATION OF GROWING CONDITIONS OF EUROPEAN MISTLETOE HYPERPARASITIC FUNGUS (PHAEOBOTRYOSPHAERIA VISCI): EFFECT OF DIFFERENT MEDIA AND ANTIBIOTICS
}

\section{OPTIMALIZÁCIA RASTOVÝCH PODMIENOK PHAEOBOTRYOSPHAERIA VISCI, HYPERPARAZITICKEJ HUBY IMELA BIELEHO: VPLYV RÔZNYCH ŽIVNÝCH MÉDIÍ A ANTIBIOTÍK}

\author{
Ildikó VARGA, ${ }^{1,2}$ Tivadar BALTAZÁR, ${ }^{3}$ Miloš PEJCHAL ${ }^{3}$ \\ Institute of Plant Protection, Georgikon Faculty, University of Pannonia, Hungary' \\ University of Helsinki, Helsinki, Finland ${ }^{2}$ \\ Mendel University in Brno, Lednice na Moravě, Czech Republic ${ }^{3}$
}

\begin{abstract}
European mistletoe (Viscum album) is an evergreen, perennial, hemiparasitic shrub, which is able to infect more than 450 woody species. Besides mechanical pruning, a hyperparasitic fungus (Phaeobotryosphaeria visci) could be a successful candidate to develop an effective biocontrol agent against mistletoe. It was necessary to find antibiotics which make the isolation easier and do not effect mycelia growth negatively under strain. Furthermore, we wanted to define a medium for optimal growth under in vitro laboratory conditions. Three different media (potato-dextrose agar, modified oatmeal agar, 1/4 PDA + V8 agar) and four antibiotics (kanamycin, ampicillin, rifampicin, nystatin) were tested. Oatmeal agar and potato-dextrose agar are optimal to maintain the fungal strains, the colony diameter was $9 \mathrm{~cm}$ on the $12^{\text {th }}$ day. All tested antibiotics are useful, except nystatin.
\end{abstract}

Keywords: Botryosphaeriaceae, oatmeal agar, antibiotic sensitivity, biological control

European mistletoe (Viscum album L.) is a globose evergreen, perennial shrub with persistent haustoria in the host (Zuber, 2004). It is able to infect more than 450 woody plants (Barney et al., 1998). European mistletoe damages forest and ornamental trees, as well as orchards. It affects negatively the height and diameter growth, and lowers the vigour of the host inducing premature mortality. The only effective control method of $V$. album is removing the infective branches (Hawksworth, 1983). We started to look for an effective control method by studying fungal pathogens infecting European mistletoe. We found and isolated one fungal species, which is able to infect the entire hemiparasitic plant. This hyperparasitic fungus is Phaeobotryosphaeria visci (Kalchbr.) A. J. L. Philips \& Crous [Syn.: Botryosphaeria visci (Kalchbr.) Arx \& E. Müll.; anamorph: Sphaeropsis visci (Fr.) Sacc.], a dark-spored ascomycete of the Botryosphaeriaceae (Varga et al., 2012). Use of this hyperparasite fungus species in biological control was studied by Karadžić and Lazarev (2005), and Varga et al. (2012). Symptoms and the optimal temperature for mycelial growth of this pathogen was reported first by Stojanović (1989), furthermore, he studied a few media for the in vitro maintenance.

Using antibiotics is general in the maintenance of pure cultures and strains. Ampicillin is a beta-lactam antibiotic that inhibits the cell wall biosynthesis and causes lytic cell death. Kanamycin is an aminoglycoside antibiotic, which binds the $16 \mathrm{~S}$ rRNA component of the 30 S ribosome subunit. Rifampicin, a semi-synthetic antibiotic inhibits DNAdependent RNA synthesis by inhibiting RNA-polymerase (Kohanski et al., 2010). Nystatin (amphotericin B) is a polyane antifungal drug which binds with ergosterol, a component of fungal cell membranes (Ghannoum and Rice, 1999).

The objectives of the present study were (i) to investigate further media which results in significantly higher mycelial growth providing better optimal conditions for maintaining the fungal strains, (ii) to test more antibiotics which could be used during the isolation of this pathogen without negative effects on spore germination and mycelial growing. For this purpose, four antibiotics (ampicillin, kanamycin, rifampicin and nystatin) and three natural media (potato dextrose agar, modified oatmeal agar and $1 / 4$ PDA + V8 agar) were used during the experiments.

\section{Material and methods}

Diseased European mistletoe leaves were collected at Ajka, Hungary in August 2010 from silver maple (Acer saccharinum L.). Monospore culture was made according to Varga et al. (2012). The examined strain was maintained on potato dextrose agar (PDA) at $20^{\circ} \mathrm{C}$ and was passed once in a month. Mycelial growth was studied on three media: (i) PDA: Potato dextrose agar ( $4 \mathrm{~g}$ potato extract, $20 \mathrm{~g}$ glucose, $20 \mathrm{~g}$ agar $\mathrm{L}^{-1}$ ), (ii) OA: oatmeal agar (100 g steamed oatmeal, $20 \mathrm{~g}$ agar $\mathrm{L}^{-1}$ ), (iii) $1 / 4$ PDA + V8 agar ( $1 \mathrm{~g}$ potato extract, $5 \mathrm{~g}$ glucose, $150 \mathrm{ml}$ V8 vegetable juice (Campbell South Co.), $3 \mathrm{~g} \mathrm{CaCO}_{3^{\prime}}$ $\left.20 \mathrm{~g}_{\text {agar }} \mathrm{L}^{-1}\right)$ in five repeats at $25^{\circ} \mathrm{C}$. The effects of antibiotics were studied on potato dextrose agar (PDA) at $25^{\circ} \mathrm{C}$, the concentrations of antibiotics were (i) ampicillin $100 \mathrm{mg} \mathrm{L}^{-1}$, (ii) kanamycin $30 \mathrm{mg} \mathrm{L}^{-1}$, (iii) rifampicin $100 \mathrm{mg} \mathrm{L}^{-1}$, (iv) nystatin $50 \mathrm{mg} \mathrm{L}^{-1}$. One-week-old pure cultures growing on PDA 
medium were used as inocula. Discs ( $5 \mathrm{~mm}$ in diameter) containing mycelia were transferred to the center of $90 \mathrm{~mm}$ Petri-dishes. Colony diameters were measured every second day until the $12^{\text {th }}$ day.

The statistical analyses were performed using the statistical program $\mathrm{R}$ version 2.15.1. (R Development Core Team 2012), and for editing $R$ scripts, Tinn-R code editor was used (Faria 2011). For characterisation of the relationship between time and raising of mycelia growth were used marginal regression models from package "nlme" (Pinheiro et al., 2011), and to compare average mycelia diameter, one-way analysis of variance (ANOVA) type I (sequential) sum of squares was used. For multiple comparisons, the Dunnett-Tukey-Kramer pairwise multiple comparison test was used. Model checking was carried out with the help of diagnostics plots.

\section{Results and discussion}

\section{Effect of media}

The colour of mycelia was white on $\mathrm{OA}$ and the colony had filamentous, downy structure with marked growing belt. Mycelial growth on PDA and $1 / 4$ PDA + V8 agar was slower and the colonies were morphologically different. Surface pigmentation was initially white, later it turned to dirty grey from the inoculation point. The colony was lobed (rosette-like) with undulated margins (Fig. 1).

During marginal regression analysis we found statistically significant difference between the growth of mycelia and medium type (media: $F_{1,99}=6.13 ; p=0.003$; day: $F_{1,99}=2785, p<0.001$; media-
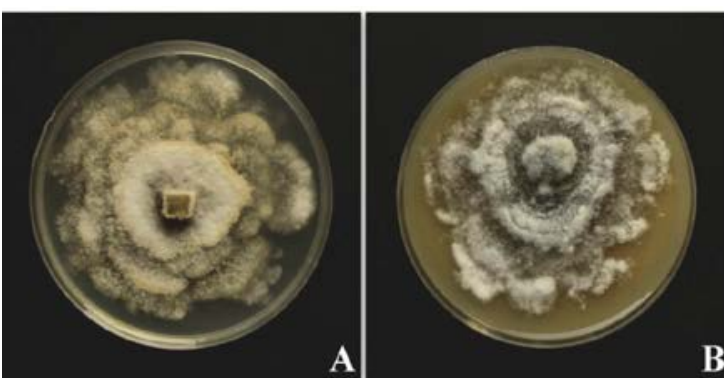

Figure 1

(A) P. visci cultures grown on potato dextrose agar; (B) 1/4 PDA + V8 agar; (C) modified oatmeal agar

Obrázok 1 (A) Kultúry $P$. visci kultivované na zemiakovo-dextrózovom agare (PDA); (B) 1/4 PDA + V8 agare; (C) modifikovanom ovsenom agare
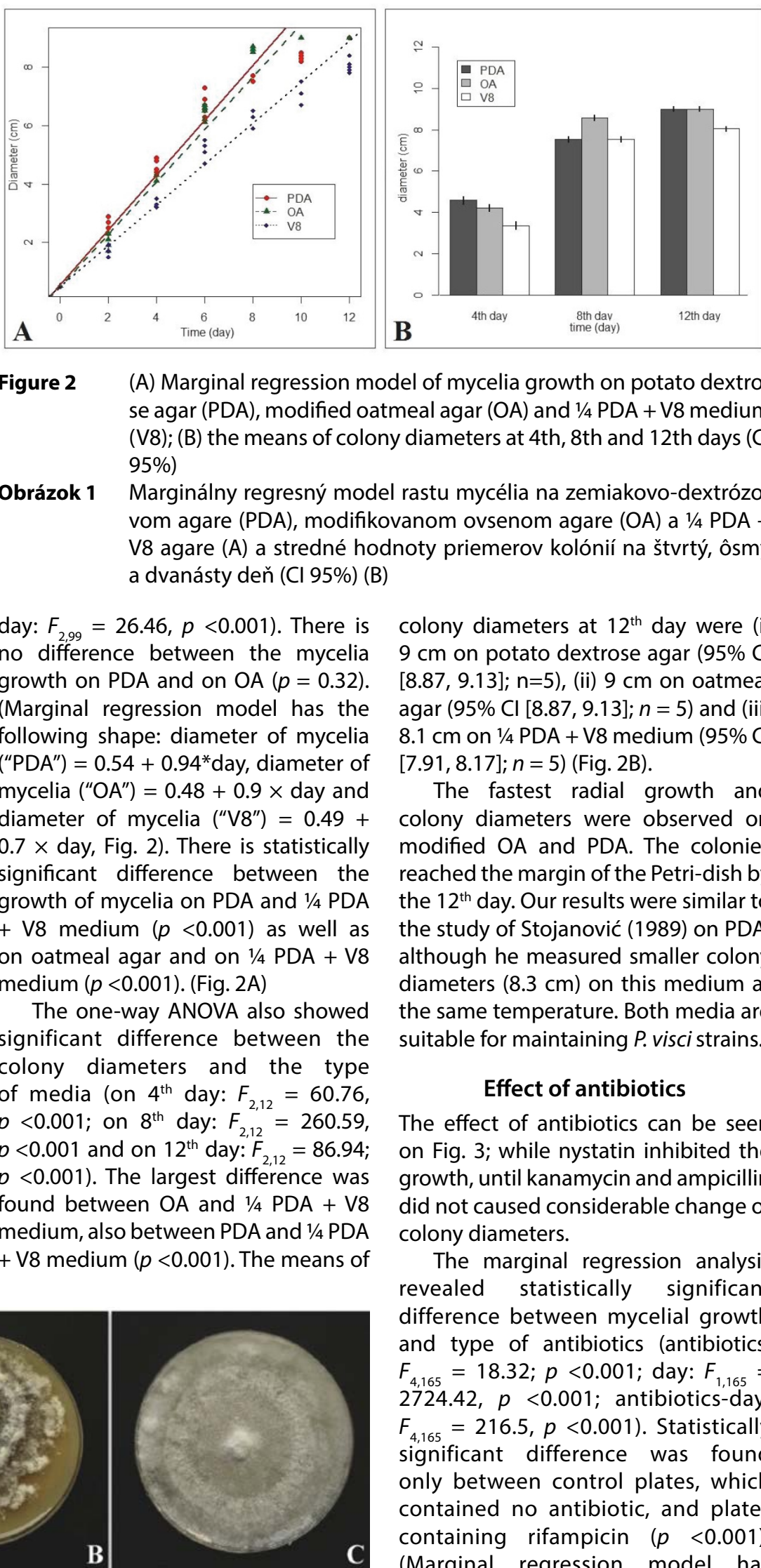

Figure 2 (A) Marginal regression model of mycelia growth on potato dextrose agar (PDA), modified oatmeal agar (OA) and $1 / 4$ PDA + V8 medium (V8); (B) the means of colony diameters at 4 th, 8 th and 12 th days $(\mathrm{Cl}$ 95\%)

Obrázok 1 Marginálny regresný model rastu mycélia na zemiakovo-dextrózovom agare (PDA), modifikovanom ovsenom agare (OA) a 1/4 PDA + V8 agare $(A)$ a stredné hodnoty priemerov kolónií na štvrtý, ôsmy a dvanásty deň (Cl 95\%) (B)

day: $\left.F_{2,99}=26.46, p<0.001\right)$. There is no difference between the mycelia growth on PDA and on OA $(p=0.32)$. (Marginal regression model has the following shape: diameter of mycelia $\left(\right.$ "PDA") $=0.54+0.94^{*}$ day, diameter of mycelia ("OA") $=0.48+0.9 \times$ day and diameter of mycelia ("V8") $=0.49+$ $0.7 \times$ day, Fig. 2). There is statistically significant difference between the growth of mycelia on PDA and $1 / 4$ PDA + V8 medium $(p<0.001)$ as well as on oatmeal agar and on $1 / 4$ PDA + V8 medium ( $p<0.001$ ). (Fig. $2 A$ )

The one-way ANOVA also showed significant difference between the colony diameters and the type of media (on $4^{\text {th }}$ day: $F_{2,12}=60.76$, $p<0.001$; on $8^{\text {th }}$ day: $F_{2,12}^{2,12}=260.59$, $p<0.001$ and on $12^{\text {th }}$ day: $F_{2,12}=86.94$; $p<0.001)$. The largest difference was found between OA and $1 / 4$ PDA + V8 medium, also between PDA and $1 / 4$ PDA $+V 8$ medium $(p<0.001)$. The means of

colony diameters at $12^{\text {th }}$ day were (i) $9 \mathrm{~cm}$ on potato dextrose agar $(95 \% \mathrm{Cl}$ $[8.87,9.13] ; \mathrm{n}=5$ ), (ii) $9 \mathrm{~cm}$ on oatmeal agar (95\% Cl [8.87, 9.13]; $n=5)$ and (iii) $8.1 \mathrm{~cm}$ on $1 / 4 \mathrm{PDA}+\mathrm{V} 8$ medium $(95 \% \mathrm{Cl}$ [7.91, 8.17]; $n=5$ ) (Fig. 2B).

The fastest radial growth and colony diameters were observed on modified OA and PDA. The colonies reached the margin of the Petri-dish by the $12^{\text {th }}$ day. Our results were similar to the study of Stojanović (1989) on PDA, although he measured smaller colony diameters $(8.3 \mathrm{~cm})$ on this medium at the same temperature. Both media are suitable for maintaining $P$. visci strains.

\section{Effect of antibiotics}

The effect of antibiotics can be seen on Fig. 3; while nystatin inhibited the growth, until kanamycin and ampicillin did not caused considerable change of colony diameters.

The marginal regression analysis revealed statistically significant difference between mycelial growth and type of antibiotics (antibiotics: $F_{4,165}=18.32 ; p<0.001$; day: $F_{1,165}=$ 2724.42, $p<0.001$; antibiotics-day: $\left.F_{4,165}=216.5, p<0.001\right)$. Statistically significant difference was found only between control plates, which contained no antibiotic, and plates containing rifampicin ( $p<0.001)$. (Marginal regression model has the following shape: diameter of mycelia ("control") $=0.52+0.95 \times$ day; diameter of mycelia ("AMP") = $0.51+0.87 \times$ day, diameter of mycelia 

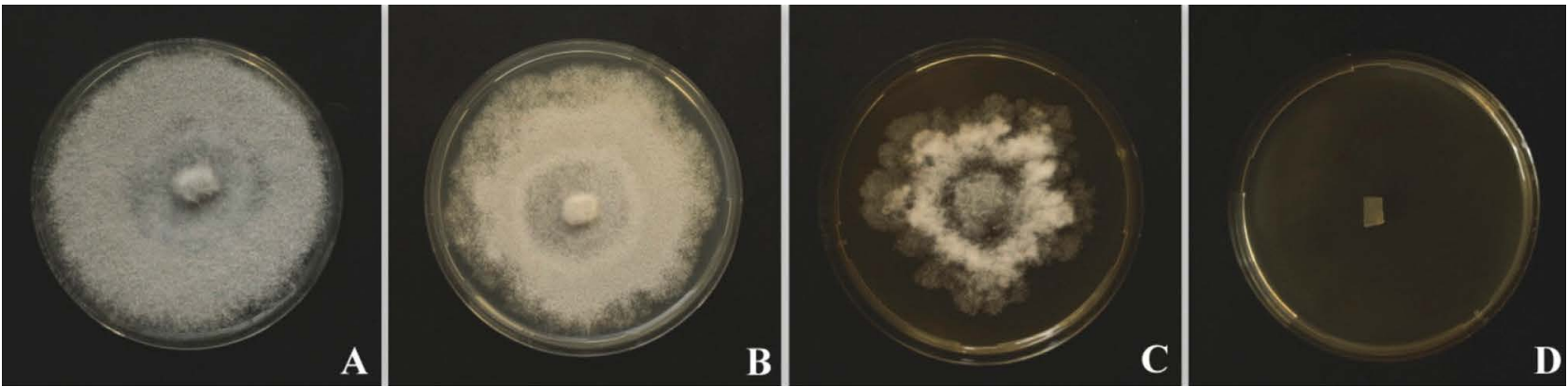

Figure 3 Effect of antibiotics on the colony diameters: (A) ampicillin; (B) kanamycin, (C) rifampicin; (D) nystatin

Obrázok 3 Vplyv antibiotík na priemer kolónií: (A) ampicilín; (B) kanamycín; (C) rifampicín; (D) nystatín

$($ "KAN") $=0.51+0.88 \times$ day; diameter of mycelia ("NYS") $=0.5$ (no change) and diameter of mycelia ("RIF") $=0.504$ $+0.48 \times$ day.) Mycelial growth was not fully linear, because the intensity of growth became slower from the $8^{\text {th }}$ day (Fig. 4A).

The one-way ANOVA revealed that there is significant difference between the diameter of mycelia and antibiotics (on $4^{\text {th }}$ day: $F_{4,20}=270.81, p<0.001$; on $8^{\text {th }}$ day: $F_{4,20}=45.786, p<0.001$ and on $12^{\text {th }}$ day: $\left.F_{4,20}=2718.4 ; p<0.001\right)$. Significant difference was found between control plates and rifampicin content respectively, between control plates and nystatin ( $p<0.001$ in both cases). There is no statistically significant difference between control plates and ampicillin content as well as control plates and kanamycin content $(p=0.09)$. The means of colony diameters on $12^{\text {th }}$ day were (i) $9 \mathrm{~cm}$ on control plates $(95 \% \mathrm{Cl}[8.85,9.15]$;
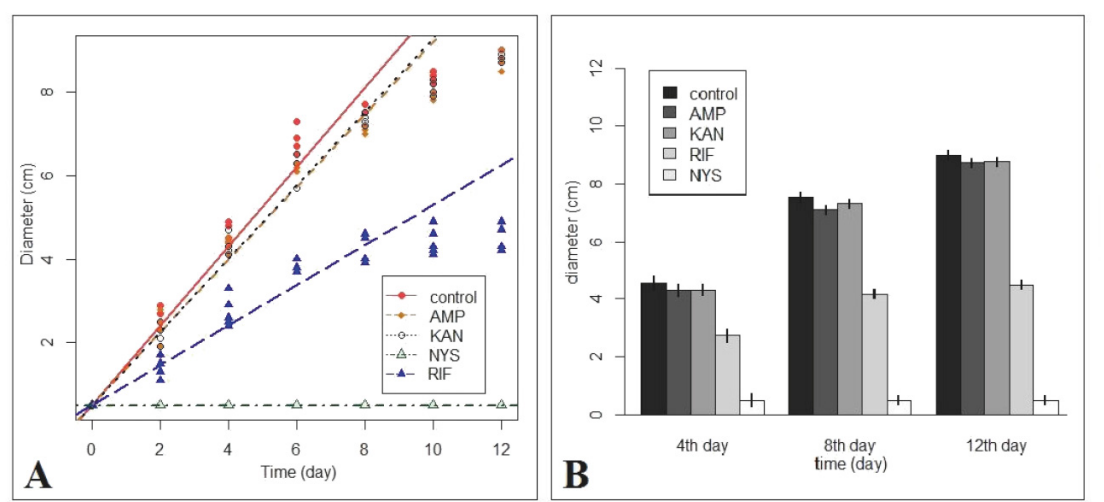

Figure 4

Marginal regression model of mycelial growth on potato dextrose agar containing different antibiotics: (A) no antibiotic (Control), ampicillin (AMP), kanamycin (KAN), rifampicin (RIF), nystatin (NYS); (B) the means of colony diameters at $4^{\text {th }}, 8^{\text {th }}$ and $12^{\text {th }}$ days $(\mathrm{Cl} 95 \%)$

Obrázok 4 Marginálny regresný model rastu mycélia na zemiakovo-dextrózovom agare $s$ antibiotikami: (A) kontrolná skupina bez antibiotík (control), ampicilín (AMP), kanamycín (KAN), rifampicín (RIF), nystatín (NYS); (B) stredné hodnoty priemerov kolónií na štvrtý, ôsmy a dvanásty deň (CI 95 \%)

$n=5)$, (ii) $8.7 \mathrm{~cm}$ in case of ampicillin content (95\% Cl $[8.61,8.91] ; n=5)$, (iii) $8 \mathrm{~cm}$ in case of kanamycin content . $\mathrm{Cl}[4.33,4.63] ; n=5)$. No growth was obsered on plates containing nystatin.

The antifungal effect of nystatin prevailed definitely, since there was no growth on plates containing . Rifampicin, which is suitable mycobacteria species had negative effect on the radial growth. Even though the presence of this antibiotic caused more than $50 \%$ decrease in colony diameters, its use would be in case of heavily infected kanamycin which can be used against wide range of bacteria had low effect on the colonies, so these antibiotics can be used freely for the maintenance of pure cultures. 
nutné identifikovat’ antibiotiká, ktoré umožnia jednoduchú izoláciu huby a nebudú mat' negatívny vplyv na rast mycélia. Chceli sme tiež nájst' živné médium, ktoré by umožňovalo optimálny rast $v$ laboratórnych podmienkach in vitro. Testovali sme tri druhy živných médií (zemiakovo-dextrózový agar, modifikovaný ovsený agar a 1/4 PDA+V8 agar) a štyri druhy antibiotík (kanamycín, ampicilín, rifampicín a nystatín). Modifikovaný ovsený agar a zemiakovo-dextrózový agar zabezpečili optimálny rast, stredná hodnota priemeru kolónií na dvanásty deň dosiahla $9 \mathrm{~cm}$. Všetky testované antibiotiká s výnimkou nystatínu boli na zvolený účel vhodné.

Klúčové slová: Botryosphaeriaceae, ovsený agar, citlivost' na antibiotiká, biologická kontrola

\section{Acknowledgement}

This study was supported by the CIMO Fellowship Grant, Finland provided to Ildikó Varga and by project no. 7/2012/591, obtained from the Internal Grant Agency of MENDELU in Brno provided to Tivadar Baltazár.

\section{References}

BARNEY, C. W. - HAWKSWORTH, F. G. et al. 1998. Hosts of Viscum album. In: Eur. J. For. Path., vol. 28, 1998, pp. 187-208.

FARIA, J. C. 2011. Resources of Tinn-R GUI/Editor for R Environment. UESC, Ilheus, Brasil. 2011.

GHANNOUM, M. A. - RICE, L. B. 1999. Antifungal agents: mode of action, mechanisms of resistance, and correlation of these mechanisms with bacterial resistance. In: Clin. Microbiol. Rev., vol. 12, 1999, pp. 501-517.

HAWKSWORTH F. G. Mistletoes as forest parasites. In: Calder, M. Bernhardt, P. (eds) The biology of mistletoes. Acad. P. Sydney, Australia. 1983, pp. 317-333. ISBN 0-12-155055-9.
KARADŽIĆ, D. - LAZAREV, V. Najznačajnije parazitske i saprofitske gljive na beloj imeli (Viscum album L.) i mogućnost njihovog korišćenja u biokontroli. In: Bulletin Faculty of Forestry, University of Bajna Luka. 2005, no. 3, pp. 35-46.

KOHANSKI, M. A. - DWYER, D. J. - COLLINS, J. J. 2010. How antibiotics kill bacteria: from targets to networks. In: Nat. Rev. Microbiol., vol. 8, 2010, pp. 423-435.

PHILLIPS, A. J. L. - ALVES, A. et al. 2008. Resolving the phylogenetic and taxonomic status of dark-spored teleomorph genera in the Botryosphaeriaceae. In: Persoonia, vol. 21, 2008, pp. 29-55.

PINHEIRO, J. - BATES, D. - DEBROY, S. - SARKAR, D. and R Development Core Team (2011) nlme: Linear and Nonlinear Mixed Effects Models. R package version 3.1-100.

R Development Core Team (2012) R: A language and environment for statistical computing. R Foundation for Statistical Computing, Vienna, Austria. ISBN 3-900051-07-0. http://www.R-project.org/

STOJANOVIĆ, S. 1989. The investigation of Sphaeropsis visci (Salm.) Sacc. and Colletotrichum gloeosporoides (Sacc.) Penz., parasite on European mistletoe (Viscum album ssp. typicum Beck). In Zastita Bilja., vol. 40, 1989, pp. 493-503.

VARGA, I. - TALLER, J. et al. 2012. Leaf-spot disease on European mistletoe (Viscum album) caused by Phaeobotryosphaeria visci: a potential candidate for biological control. In: Biotech. Lett., vol. 34, 2012, no. 6, pp. 1059-1065.

\section{Contact address:}

Ildikó Varga, Institute of Plant Protection, Georgikon Faculty, University of Pannonia. H-8360 Keszthely, Deák str. 57, Hungary, phone: +3683545220, e-mail: ildikovarga@ hotmail.hu 